\title{
New species of the genus Boletina Winnertz (Diptera: Mycetophilidae) from Fennoscandia
}

\author{
Alexei Polevoi \& Kjell Hedmark
}

Polevoi, A. \& Hedmark, K. 2004: New species of the genus Boletina Winnertz (Diptera: Mycetophilidae) from Fennoscandia. _ Entomol. Fennica 15:23-33.

Nine new species of the fungus-gnat genus Boletina Winnertz (B. falcata sp. n., B. hedstroemi sp. n., B. struthioides sp. n., B. kivachiana sp. n., B. fennoscandica sp. n., B. lapponica sp. n., B. subtriangularis sp. n., B. atridentata sp. n. and B. cordata sp. n.) are described from Russian Karelia, Finland and Sweden. The descriptions are based on recently collected specimens as well as on the old material deposited in the collection of the Museum of Natural History, Helsinki, Finland. Most of the collecting localities are situated in oldgrowth reservations or habitats suggested to protection. Detailed descriptions and illustrations of genitalia are given. Ecological data and information on closely related species are provided.

Alexei Polevoi, Forest Research Institute, Pushkinskaya 11, 185610, Petrozavodsk, Russia; E-mail: alexei.polevoi@krc.karelia.ru

Kjell Hedmark, Kyrkvägen 17, S-96030 Vuollerim, Sweden; E-mail: kjell. hedmark@same.net

Received 12 November 2002, accepted 02 September 2003

\section{Introduction}

The end of the 20th century was marked by increasing interest in fungus gnats in the Scandinavian countries and northwest Russia. Large-scale trapping projects and other intensive collecting in Russian Karelia, Finland, Sweden and Norway gave extensive material of Mycetophilidae and related families of Diptera. During the treatment of these materials, considerable numbers of new and otherwise remarkable species were found. Recently-published results incorporate species lists from certain areas, reviews of most interesting records and descriptions of new species (Plassmann 1990, 1999, Søli 1993, 1994, Zaitzev \& Økland 1994, Polevoi 1995, 2001, Zaitzev \& Polevoi 1995, 2001, Økland 1995, Økland \& Zaitzev 1997, Hedmark 1998, 2000). The present work focuses on the new species belonging to the genus Boletina Winnertz, which is one of the most diverse but simultaneously most poorly studied genera of Mycetophilidae.

The paper is based on materials collected during recent years in Russian Karelia, Finland and Sweden. Older specimens of the genus Boletina stored in the collection of Helsinki Zoological Museum have also been revised. All materials, except several individuals from Finnish Lapland (Kilpisjärvi and Utsjoki), were obtained in typical taiga landscapes. In many cases they originate from old-growth forest, preserved in protected areas. Collecting localities are shown in Fig. 1. General information on the most important points is published elsewhere: Paanajärvi National Park (Heikkilä et al. 2000); Kostomuksha and adjacent areas (Lindholm et al. 1997); Kivach Nature Reserve (Salo 1986); Koitajoki, Tolvojärvi and adjacent areas (Blomberg et al. 1999, Hokkanen 


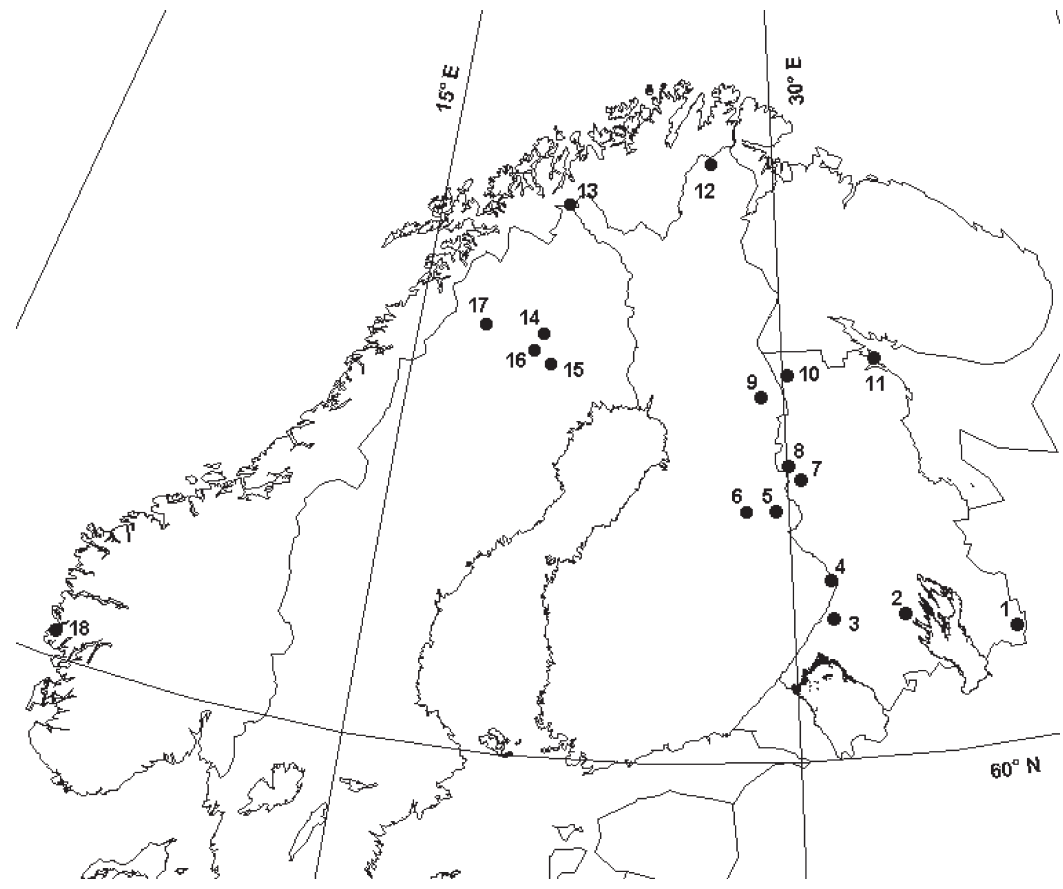

Fig. 1. Collecting localities in Fennoscandia. 1 - Chumbasozero; 2 Kivach Nat. Res.; 3 Tolvojärvi; 4 - Koitajoki, Tapionaho; 5 - Kuhmo; 6 - Sotkamo; 7 - Kostomuksha; 8 - Ladvozero, Kamennoe ozero; 9 Kuusamo; 10 - Paanajärvi Nat. Park; 11 Kartesh; 12 - Utsjoki; 13 - Kilpisjärvi; 14 Muddus Nat. Park; 15 - Vuollerim; 16 Jokkmokk; 17 - Kvikkjokk; 18 - Bergen, Osteröy.
2001); Kuhmo and Sotkamo (Komonen 2001); localities in Sweden (Engelmark 1981, Karström 1997, Hedmark 2000). Abbreviations and numbers on the labels following country name refer to biogeographic provinces and $27^{\circ} \mathrm{E} / 33^{\circ} \mathrm{E}$ coordinates (Heikinheimo \& Raatikainen 1971, Humala 1998). Type specimens are deposited in the collections of Zoological Institute, St. Petersburg (ZISP) and Finnish Museum of Natural History, Helsinki (FMNH). Other material is available at the Forest Research Institute, Petrozavodsk (FRIP) and in Kjell Hedmark's private collection (KHPC). For certain old specimens stored in FMNH with no detailed data on the label we give the local collection number.

All individuals in the type series are dry pinned. Genitalia were treated with standard methods (heating in a solution of potassium hydroxide followed by washing in water and alcohol or neutralisation in pure acetic acid) and then transferred into glycerin for detailed study. Later they were stored in this medium in microvials pinned together with the appropriate specimen. Descriptions are based on all specimens in the type series. Some of the studied specimens are quite old and some were initially stored in alcohol, which resulted in color fading. Coloration characters should thus be used with care and genitalia must be studied for reliable identification.

\section{Description of new species}

\section{Boletina falcata sp. n. (Fig. 2)}

Holotype: 1 ô, Finland, Kb: 698:72, Tapionaho (170 m), 25-28.VIII.1994, Polevoi (ZISP). Paratypes: 3 $え$, same place, 25.VIII-7.IX.

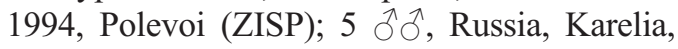
Kpoc: $7155: 384,10 \mathrm{~km} \mathrm{SW}$ of Kostomuksha (170 m a.s.1.), 23-27.VIII.1995, Polevoi (ZISP); 2 ふ઼̊, Sweden, Lule Lappmark, Kvikkjokk, Prinskullestigen (600 m), 6.VIII.1997, Hedmark (ZISP); 1 ô, Sweden, Lule Lappmark, Jokkmokk, Serri Nat. Res. (265 m), 17.VIII. 1997, Hedmark (ZISP).

Other material. Finland: 5 ふ઼ે, Tapionaho, 25.VIII-7.IX.1994, Polevoi (FRIP); 60 $\widehat{\jmath} \widehat{\jmath}$ from Kuhmo and Sotkamo area (Elimyssalo, Jauhovaara, Iso-Matojärvi, Juntinvaara, Ypykkävaara, Luhtavaara, Pellinkangas, Pitkävaara, Teerisuo, Tulisuo-Varpusuo, Urpovaara, Vepsä, Yonkeri, Yuortanansalo), 8.VIII-11.IX.1997,

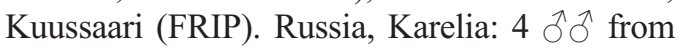




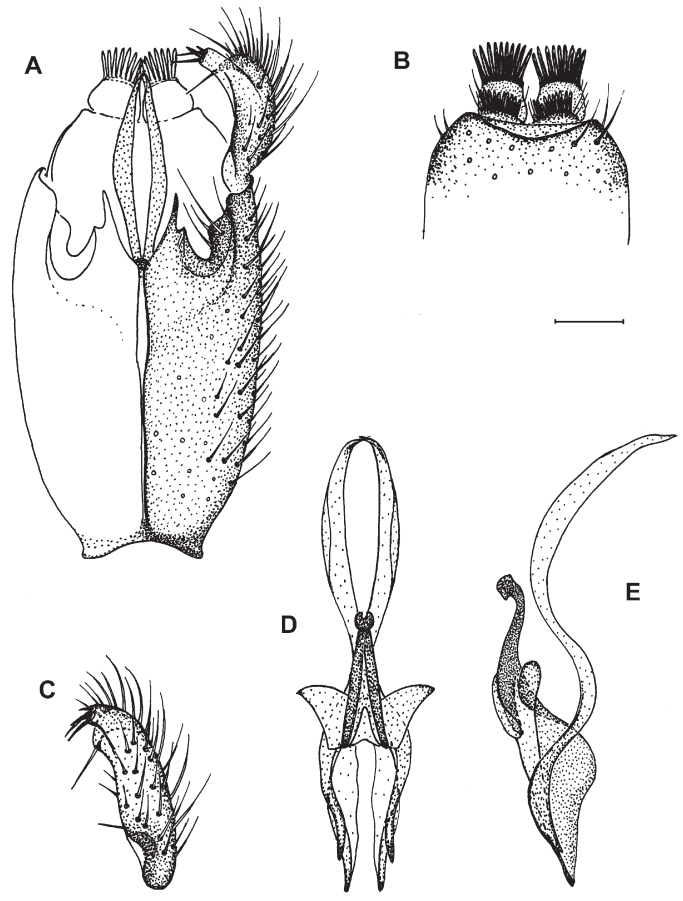

Fig. 2. Boletina falcata sp. n. - A. Male genitalia, ventral view. - B. Tergite IX. - C. Gonostylus. - D. Aedeagus and parameres, ventral view. - E. Same, lateral view. Scale bars $0.12 \mathrm{~mm}(\mathrm{~A}, \mathrm{~B}, \mathrm{D}, \mathrm{E})$ and 0.1 $\mathrm{mm}(\mathrm{C})$.

Paanajärvi National Park (Siltajoki, Valkojärvi, Nupajärvi), 20-30.VI.1998, 19-24.VIII.1999, Polevoi (FRIP). Sweden, Lule Lappmark: 2 ఏ઼,, Gällivare, 1 km E Muddus Nat. Park (460 m), 19.VIII.2001, Hedmark (KHPC); 1 गे, Kvikkjokk, Prinskullestigen $(600 \mathrm{~m})$, 6.VIII.1997, Hedmark (KHPC); 1 ô, Jokkmokk, Serri Nat. Res. (265 m), 17.VIII.1997, Hedmark (KHPC).

Male. Head black. Clypeus black to blackish brown. Mouthparts and palps dark brown, distal palpomeres paler. Antennae dark brown. Sixth flagellomere about twice as long as wide. Mesonotum black, thinly grey dusted, with three faintly shining longitudinal stripes. Pleurae dark brown to black, matt. Anterior spiracles yellowish in some specimens. Laterotergite haired. Coxae, femora and tibiae yellow, trochanters darkened. Tarsal claws of fore leg short and rounded, all others with thickened lobes. Leg ratios: $\mathrm{t} 1$ :bt $1=1.3-1.5, \mathrm{t} 2: \mathrm{bt} 2=1.4-1.6, \mathrm{t} 3: \mathrm{bt} 3=$ 1.6-1.8. Wing length $3.5-4.1 \mathrm{~mm}$. Wings hya- line. Costa extending beyond tip of R5 to approximately $1 / 3$ of the distance between R5 and M1. Sc bare, ending above, slightly beyond or before base of Rs. Sc2 present, slightly distal to the middle of Sc. Stem of Median fork 1.1-1.5 times as long as r-m. Halteres yellow. Abdomen and genitalia dark brown to black, slightly shining. Genitalia as in Fig. 2. Sternal submedian appendages of gonocoxites pointed apically, with accessory subapical outgrowth. Gonostylus slender with four spinous bristles at apex and one long subapical bristle medially. Tergite IX rectangular with distal margin slightly concave to almost straight. Cerci subquadrate with apical comb of strong spines and one row of smaller spines at base. Parameres long and falciform in lateral view.

Female unknown.

Remarks. The species is apparently related to the group of species near $B$. nitida Grzegorzek, 1885 and $B$. dispecta Dziedzicki, 1885, but differs in particular by long parameres and the shape of gonostylus. The material has been collected with sweepnet and Malaise traps in varying coniferous stands and in embogged forest. Two males of this species are known from Norway (G. Søli, pers. comm.): 1 đ, HOY: Osteröy, Lötvedtvann, 19.IX.1982, Søli; 1 Oे, HOY: Bergen, Asköy, Erdal, 17.IX.1982, Andersen. Species' name refers to the falcate shape of the parameres.

\section{Boletina hedstroemi sp. n. (Fig. 3)}

Holotype: 1 ठ̊, Sweden, Lule Lappmark, Gällivare, $1 \mathrm{~km}$ E Muddus Nat. Park (460 m) 19.VIII.2001, Hedmark (ZISP). Paratypes: 10 , Finland, Ok: 7104:599, Kuhmo, Näveri (170 m), 25.VIII-7.IX.1997, Kuussaari (ZISP); 3 $\widehat{\jmath}$, Finland, Ok: 7135:594, Kuhmo, Pellinkangas (170 m), 25.VIII-28.IX.1997, Kuussaari (ZISP); 1 Oे, Russia, Karelia, Kon: Kivach Nat. Res. (70 m), 30.VIII-3.IX.1991, Polevoi (ZISP).

Other material. 1 $\widehat{\jmath}$, Sweden, Lule Lappmark, Gällivare, 1 km E Muddus Nat. Park, (460 m), 19.VIII.2001, Hedmark (KHPC).

Male. Head black. Clypeus black, mouthparts and first palpomere dark brown, distal palpomeres yellow. Antennae dark brown, base of first flagellomere paler. Sixth flagellomere 

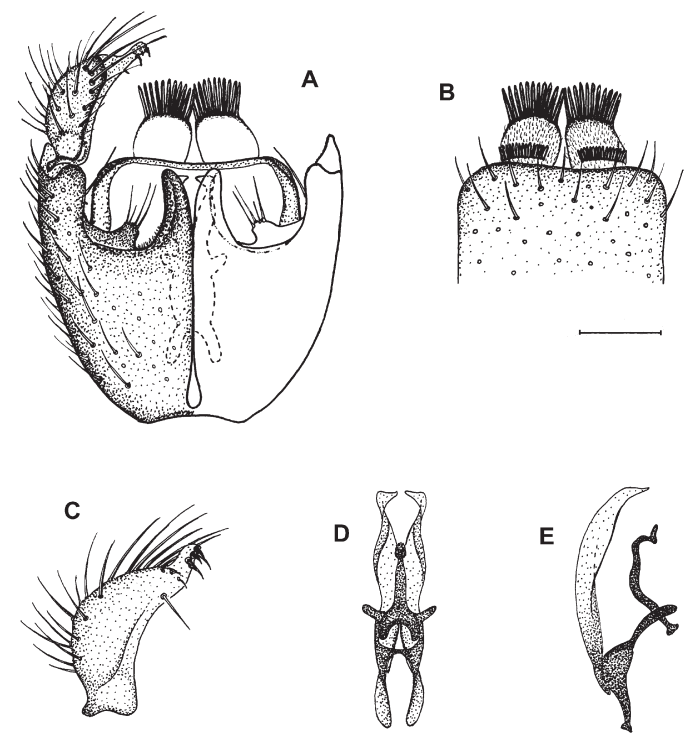

Fig. 3. Boletina hedstroemi sp. n. - A. Male genitalia, ventral view. - B. Tergite IX. - C. Gonostylus. - D. Aedeagus and parameres, ventral view. - E. Same, lateral view. Scale bars $0.12 \mathrm{~mm}(\mathrm{~A}, \mathrm{~B})$ and $0.1 \mathrm{~mm}$ (C-E).

about twice as long as wide. Mesonotum black, thinly grey dusted, with faint median longitudinal stripe. Traces of lateral mesonotal stripes can be observed in some specimens. Pleurae dark brown to almost black, matt. Anterior spiracles yellowish brown. Laterotergite haired. Coxae, femora and tibiae yellow, trochanters darkened. Tarsal claws unmodified. Leg ratios: $\mathrm{t} 1: \mathrm{bt} 1=1.3, \mathrm{t} 2: \mathrm{bt} 2$ $=1.6, \mathrm{t} 3: \mathrm{bt} 3=1.7-2$.

Wing length $3.5-4 \mathrm{~mm}$. Wings hyaline. Costa extending beyond tip of R 5 to $1 / 3$ of the distance between R5 and M1. Sc bare, ending slightly beyond base of Rs. Sc2 present, slightly distal to the middle of Sc. Stem of Median fork 1.2-1.7 times as long as $\mathrm{r}-\mathrm{m}$. Halteres yellow. Abdomen and genitalia dark brown. Genitalia as in Fig. 3. Sternal submedian appendages of gonocoxites moderately long, rounded apically. Additional setose lobe present laterally to appendages. Gonostylus produced apically into a short process, bearing five spinous bristles. Long subapical seta developed medially. Tergite IX rectangular, distal margin slightly concave to almost straight. Cerci oval with apical comb of strong spines and one row of shorter spines near base. Parameres relatively short, pointed to apices, arcuate in lateral view.
Female unknown.

Remarks. The species is closely related to $B$. bidenticulata Sasakawa \& Kimura 1974, but can be distinguished by the shape of the parameres and by the setose lobe lateral to the sternal submedian appendages of the gonocoxites. The material has been collected with sweepnet, Malaise, bait and light traps in Myrtillus type spruce dominated stands and old, embogged Carex globularis forest. The species is named in honour of the dipterologist Dr. Lars Hedström, Museum of Evolution, Zoological Department, Uppsala University. In 1994 he initiated the mycetophilid studies of K. Hedmark.

\section{Boletina struthioides sp. n. (Fig. 4)}

Holotype: 1 ภ, Russia, Karelia, Kpoc: 719:35, Ladvozero (220 m), 11.VII.1996, Polevoi (ZISP).

Paratypes: 5 ふふ઼, same place, 10-15.VII. 1996, Polevoi (ZISP); 1 §, Russia, Karelia, Kk: 736:53, Kartesh (25 m), 24-27.VII.1996, Polevoi
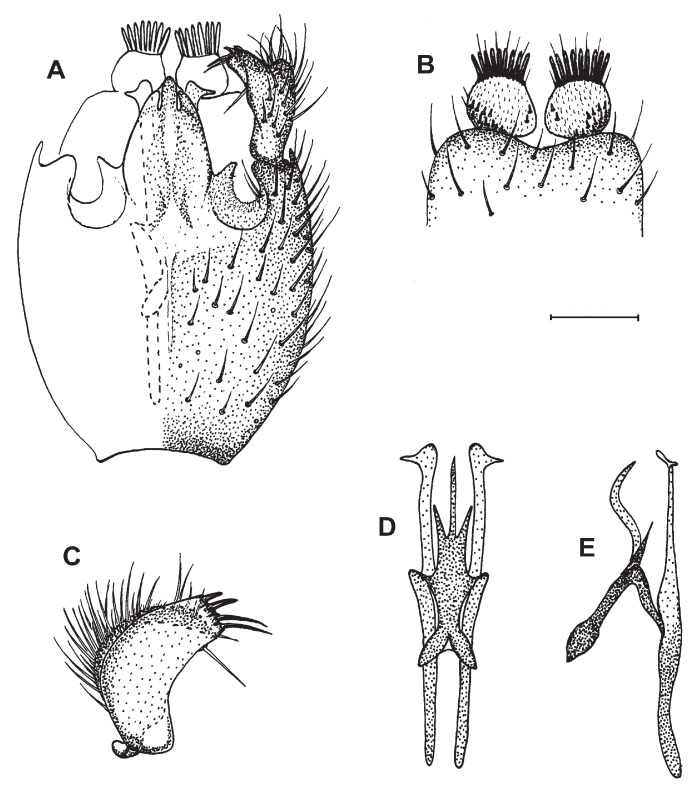

Fig. 4. Boletina struthioides sp. n. - A. Male genitalia, ventral view. - B. Tergite IX. - C. Gonostylus. - D. Aedeagus and parameres, ventral view. - E. Same, lateral view. Scale bars $0.12 \mathrm{~mm}(A, B, D, E)$ and 0.1 $\mathrm{mm}(\mathrm{C})$. 
(ZISP); 1 ô, Finland, Le: Kilpisjärvi, 16.VIII. 1970, Tiensuu (FMNH).

Male. Head black. Clypeus black. Mouthparts and palps dark brown. Antennae dark brown. Sixth flagellomere 2-2.5 times as long as wide. Mesonotum black, thinly grey dusted, with three faintly shining longitudinal stripes. Pleurae dark brown, matt. Anterior spiracles yellow to yellowish brown. Laterotergite bare. Coxae, femora and tibiae yellow, trochanters darkened. Tarsal claws of all legs thickened and rounded. Leg ratios: $\mathrm{t} 1: \mathrm{bt} 1=1.3-1.5, \mathrm{t} 2: \mathrm{bt} 2=1.6-1.7, \mathrm{t} 3 \mathrm{:bt} 3=1.7-2$.

Wing length $3.3-3.5 \mathrm{~mm}$. Wings hyaline. Costa extending beyond tip of R5 to approximately $1 / 3$ of the distance between R 5 and M1. Sc bare, ending above or slightly before base of Rs. Sc2 present, slightly distal to the middle of Sc. Stem of Median fork 1.1-1.5 times as long as r-m. Halteres yellow. Abdomen and genitalia dark brown, faintly shining. Genitalia as in Fig. 4. Sternal submedian appendages of gonocoxites elongated, fused into united structure with three small apical lobes and two accessory projections at base. Gonostylus bears four spinous bristles at apex and one subapical bristle medially. Tergite IX rectangular with distal margin distinctly concave. Cerci trapezium shaped, with apical comb of strong spines and group of irregularly arranged spinules at base. Parameres relatively short, apically rounded with lateral beak-like process.

Female unknown.

Remarks. B. struthioides is related to other species in the sciarina group as it is defined by Hutson et al., (1980) and can be distinguished by structure of male genitalia. It has been collected with Malaise traps and sweepnet in mixed stands and adjacent meadows. The species' name refers to the parameres, which in ventral view resemble ostrich (Struthio) heads.

\section{Boletina kivachiana sp. n. (Fig. 5)}

Holotype: $1 \curvearrowright$, Russia, Karelia, Kon: Kivach Nat. Res. (70 m), 13-16.IX.1991, Polevoi (ZISP). Paratypes: 7 ठึ, same place, 11.VI-9.X.1991, Polevoi (ZISP); 1 $\hat{\jmath}$, Russia, Karelia, Kpoc: 719:36, Kamennoe ozero (245 m), 8-12.VII. 1996, Polevoi (ZISP); 1 đ, Russia, Karelia, Kton: 686:75, Chumbasozero (140 m), 22-26.VI.1996,
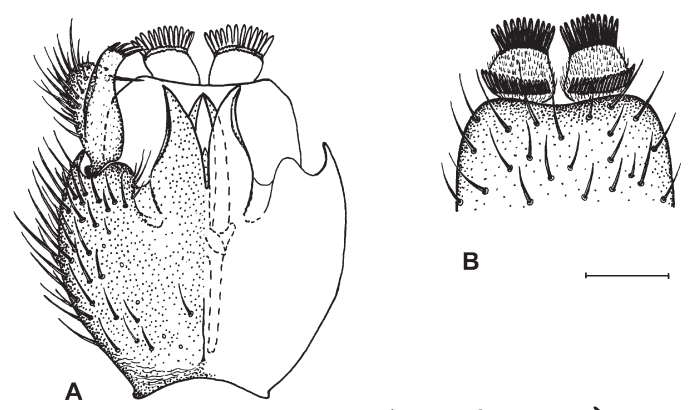

B

A
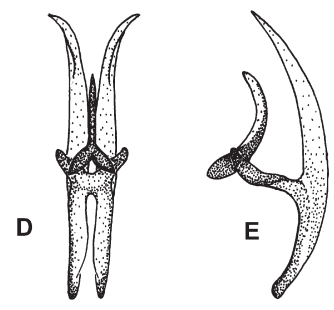

Fig. 5. Boletina kivachiana sp. n. - A. Male genitalia, ventral view. - B. Tergite IX. - C. Gonostylus. - D. Aedeagus and parameres, ventral view. - E. Same, lateral view. Scale bar $0.1 \mathrm{~mm}$.

Polevoi (ZISP); 1 ふૈ, Finland, Ok: 7128:660, Kuhmo, Juntinvaara (280 m), 15-30.IX.1997, Kuussaari (ZISP).

Male. Head black. Clypeus black, mouthparts and palps dark brown. Antennae dark brown. Sixth flagellomere about twice as long as wide. Mesonotum black, thinly grey dusted, with three faintly shining longitudinal stripes. Pleurae dark brown, matt. Laterotergite bare. Coxae, femora and tibiae yellow, trochanters darkened. Tarsal claws of all legs thickened and rounded. Leg ratios: $\mathrm{t} 1: \mathrm{bt} 1=1.3-1.4, \mathrm{t} 2: \mathrm{bt} 2=1.4-1.6, \mathrm{t} 3: \mathrm{bt} 3=$ 1.6-1.9. Wing length $2.8-3.6 \mathrm{~mm}$. Wings hyaline. Costa extending beyond tip of R5 to 1/31/ 2 of the distance between R5 and M1. Sc bare, ending slightly before base of Rs. Sc2 present, slightly distal to the middle of Sc. Stem of Median fork 1.0-1.8 times as long as r-m. Halteres yellow. Abdomen and genitalia dark brown, faintly shining. Genitalia as in Fig. 5. Sternal submedian appendages of gonocoxites elongated, wide basally, distinctly narrowing from the middle and apically pointed. Gonostylus bears five spinous bristles at apex and one strong subapical bristle medially. Tergite IX rectangular with distal margin slightly concave. Cerci trapezium shaped, with apical comb of strong spines and one row of 
shorter spines at base. Parameres short, evenly arcuate in lateral view, attenuate to apices.

Female unknown.

Remarks. B. kivachiana is related to other species in the sciarina group and can be distinguished by the structure of male genitalia. The material has been collected with Malaise and bait traps in Vaccinium and Myrtillus type coniferous stands. This species is also known from three Scottish records (P. Chandler pers. comm.). Edwards (1925) figured it under the name B. nigrofusca Dziedzicki, 1885 var. He mentioned differences from Dziedzicki's original figures but did not find them sufficient to describe a new species. B. nigrofusca however has a significantly different structure of the sternal submedian appendages of gonocoxites, which are short and rectangular. Species' name originates from Kivach Nature Reserve.

\section{Boletina fennoscandica sp. n. (Fig. 6)}

Holotype: 1 §, Sweden, Lule Lappmark, Kvikkjokk, Vallevare, Karvek (650 m), 4.IX.1998, Hedmark (ZISP). Paratypes: 1 ô, Sweden, Lule Lappmark, Jokkmokk, Muddus Nat. Park, Tuoljebäcken (345 m), 16.IX.1995, Hedmark

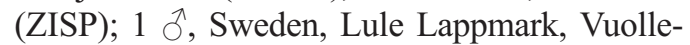
rim, Varjek, Varjekbäcken/Jovvamyren (200 m),

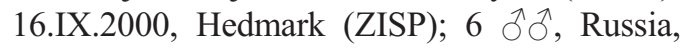
Karelia, Kon: Kivach Nat. Res. (70 m), 18.IX19.X.1990, Polevoi (ZISP); 1 đ̃, Finland, Ok: 7162:617, Kuhmo, Pitkävaara (200 m), 1225.VIII.1997, Kuussaari (ZISP).

Other material. Sweden, Lule Lappmark: 1 đ̃, Vuollerim, Nietsaktjärn (245 m), 9.IX.1995, Hedmark (KHPC);1 §, Vuollerim, Varjek, Varjekbäcken/Jovvamyren (200 m), 16.IX.2000, Hedmark (KHPC); 1 Jे, Vuollerim, Årroberget, 5 km SV Kåikul (250 m), 27. IX. 2000, Hedmark (KHPC).

Male. Head black. Clypeus black, mouthparts and palps dark brown, distal palpomeres paler in some specimens. Antennae dark brown. Sixth flagellomere 2-2.5 times as long as wide. Mesonotum black, thinly grey dusted, with three longitudinal stripes. Pleurae dark brown, matt. Anterior spiracles yellow to yellowish brown. Laterotergite bare. Fore and middle coxae,

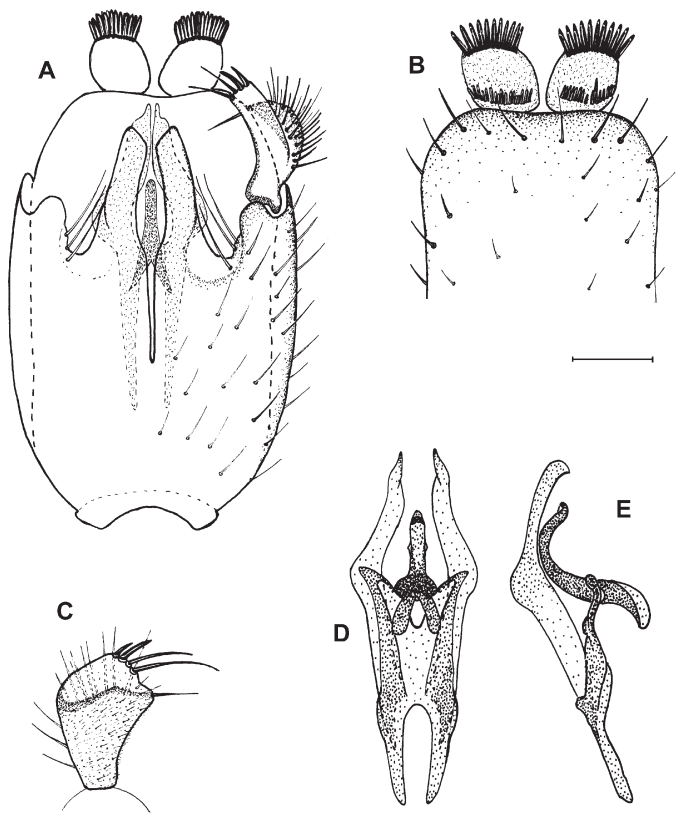

Fig. 6. Boletina fennoscandica sp. n. - A. Male genitalia, ventral view. - B. Tergite IX. - C. Gonostylus. - D. Aedeagus and parameres, ventral view. - E. Same, lateral view. Scale bar $0.1 \mathrm{~mm}$.

femora and tibiae entirely yellow, trochanters and hind coxae somewhat darkened at base. Tarsal claws of all legs thickened and rounded. Leg ratios: $\mathrm{t} 1: \mathrm{bt} 1=1.3-1.5, \mathrm{t} 2: \mathrm{bt} 2=1.4-1.5, \mathrm{t} 3: \mathrm{bt} 3=$ 1.5- 1.8. Wing length 3.3-4.2 mm. Wings hyaline. Costa extending beyond tip of R5 to approximately $1 / 3$ of the distance between R 5 and M1. Sc bare, ending above or slightly before base of Rs. Sc2 present, somewhat distal to the middle of Sc. Stem of Median fork 1.2-1.9 times as long as $\mathrm{r}-\mathrm{m}$. Halteres yellow. Abdomen and genitalia dark brown. Genitalia as in Fig. 6. Sternal submedian appendages of gonocoxites elongated, with oblique apical cut. Gonostylus bears four spinous bristles at apex and one subapical bristle medially. Tergite IX elongated rectangular with distal margin slightly concave to almost straight. Cerci subrectangular, with apical comb of strong spines and one row of smaller spines at base. Parameres relatively short, swollen and bent in the middle.

Female unknown.

Remarks. B. fennoscandica is related to other species in the sciarina group and can be distin- 
guished by the structure of male genitalia. The material has been collected with sweepnet, Malaise and bait traps in various coniferous stands and herb-rich willow-thicket at the tree-limit. Species' name originates from biogeographical region Fennoscandia.

\section{Boletina lapponica sp. n. (Fig. 7A-E)}

Holotype: 1 ふૈ, Sweden, Lule Lappmark, Vuollerim, Varjek, Varjekbäcken/Jovvamyren (200 m), 16.IX.2000, Hedmark (ZISP). Paratypes: 1 $\lesssim$, same data; $1 \curvearrowright$, Sweden, Lule Lappmark, Jokkmokk, Tjåmotis, Kuorpak (620 m), 22.IX.1998, Hedmark (ZISP); 2 ฮิ ô, Russia, Karelia, Kivach Nat. Res. (70 m), 30.IX9.X.1991, Polevoi (ZISP).

Other material. Sweden, Lule Lappmark: 2

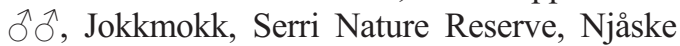
(335 m) 11.IX.2000, Hedmark (KHPC); 1 , , Vuollerim, $1 \mathrm{~km}$ SE Porsi hydroelectrical station (65 m) 13.IX.2000, Hedmark (KHPC).

Male. Head black. Clypeus black, mouthparts and palps dark brown. Palpomeres covered with dense minute hairs. Antennae dark brown. Sixth flagellomere 3.0-3.8 times as long as wide. Mesonotum black, thinly gray dusted, usually with three more or less shining longitudinal stripes. Pleurae dark brown to black. Anterior spiracles paler in some specimens. Laterotergite bare. Coxae and trochanters dark brown. Femora, tibiae and tarsi yellowish brown. Femora darkened in the proximal half, especially on the ventral side of fore and middle leg. Tarsal claws unmodified. Leg ratios: $\mathrm{t} 1: \mathrm{bt} 1=1.5-1.7, \mathrm{t} 2: \mathrm{bt} 2=$ $1.5-1.7, \mathrm{t} 3$ : bt3 $=1.7-2.0$. Wing length 3.9-4.4 $\mathrm{mm}$. Wings hyaline. Costa extending beyond tip of R5 to 1/3-1/2 of the distance between R5 and M1. Sc bare, ending well beyond base of Rs. Sc 2 present near or slightly distal to the middle of Sc. Stem of Median fork 1.1-1.5 times as long as r-m. Halteres brown, knob paler in some specimens.

Abdomen and genitalia dark brown. Genitalia as in Fig. 7A-E. Sternal submedian appendages of gonocoxites moderately long, blunt apically. Gonostylus with long median process, bearing short spine and longer bristle on tip. Long median bristle developed below process. Parameres relatively short, slender, tapered to apices. Tergite IX
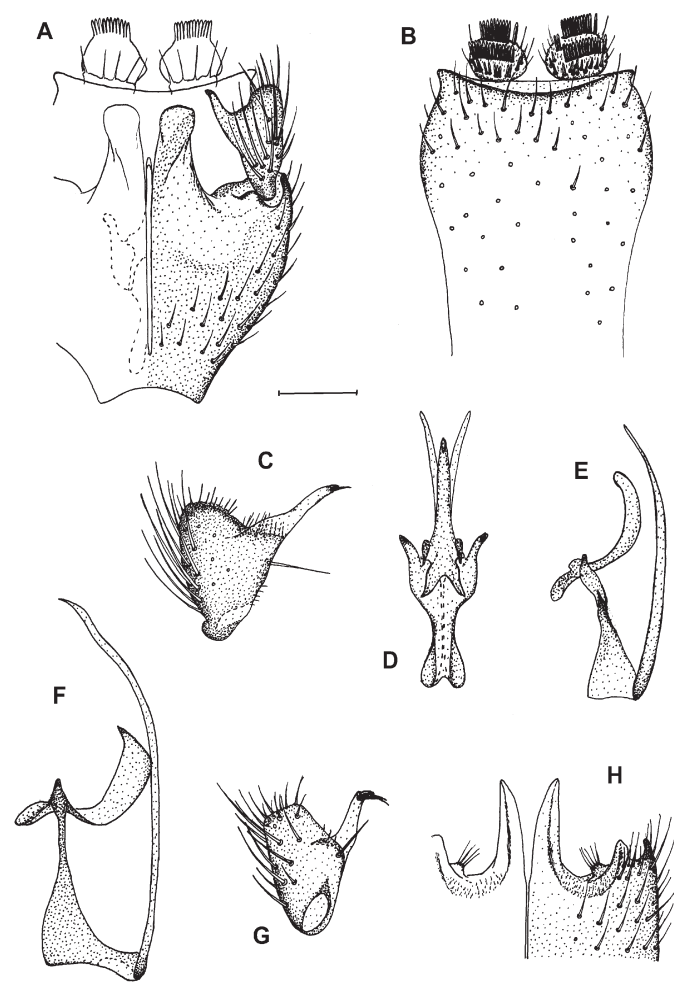

Fig. 7. Boletina spp. - A-E. B. lapponica sp. n. - F-H. B. gripha Dziedzicki (A: male genitalia, ventral view; $B$ : tergite IX; C, G: gonostylus; D: aedeagus and parameres, ventral view; E, F: same, lateral view; $\mathrm{H}$ : sternal submedian appendages of gonocoxites). Scale bars $0.12 \mathrm{~mm}(\mathrm{~A}, \mathrm{~B}, \mathrm{D}, \mathrm{E}, \mathrm{F}, \mathrm{H})$ and $0.1 \mathrm{~mm}(\mathrm{C}, \mathrm{G})$.

widened before apex, distal margin broadly and smoothly emarginate. Cerci widely oval, with apical comb of spines, one median row of smaller spines and third irregular row of basal spines.

Female unknown.

Remarks. B. lapponica is closely related to $B$. gripha Dziedzicki, 1885. The latter differs by typically entirely yellow legs, and details of male genitalia structure: sternal submedian appendages of gonocoxites tapering, parameres distinctly longer, slightly sinuous distally, gonostylus with shorter median process (Fig. $7 \mathrm{~F}-\mathrm{H}$ ). The material has been collected with Malaise traps and sweepnet in Myrtillus, herb-rich and embogged types of spruce dominated stands and in herb-rich willow habitats. Species' name indicates the area (Lapland), where most of the specimens were found. 
Boletina subtriangularis sp. n. (Fig. 8A-D)

Holotype: 1 ऽ, Russia, Karelia, Kon: 6908: 551, Kivach Nat. Res. (70 m), 17-21.IX.1990, Polevoi (ZISP). Paratypes: 1 $\hat{\jmath}$, Finland, Utsjoki (105 m), R. Frey (3047, FMNH); 1 o, Sweden, Lule Lappmark, Vuollerim, Lagnäs, Lövbäcken (60 m), 6.VII.1997, Hedmark (ZISP).

Other material. 1 $\hat{\jmath}$, Sweden, Lule Lappmark, Vuollerim, Vuollerimravinen $(85 \mathrm{~m})$, 17.VIII.2001, Hedmark (KHPC).

Male. Head black. Clypeus black, mouthparts and palps dark brown, distal palpomeres yellowish. Antennae dark brown, pedicel and base of first flagellomere yellow to yellowish brown. Sixth flagellomere about twice as long as wide. Mesonotum black, thinly grey dusted, with three faintly shining longitudinal stripes. Pleurae dark brown to black, matt. Anterior spiracles yellowish brown. Laterotergite bare. Coxae, femora and tibiae yellow, trochanters darkened. Tarsal claws unmodified. Leg ratios: $\mathrm{t} 1 \mathrm{bt} 1=1.3-1.5, \mathrm{t} 2: \mathrm{bt} 2=$ $1.3-1.4$, t3:bt3 $=1.7-1.8$. Wing length $3.0-3.9$ $\mathrm{mm}$. Wings hyaline. Costa extending beyond tip of R5 to 1/3-1/2 of the distance between R5 and M1. Sc ending above base of Rs. Sc2 present, slightly distal to the middle of Sc. Stem of Median fork 1.1-1.6 times as long as r-m. Halteres yellow. Abdomen and genitalia dark brown to entirely black. Genitalia as in Fig. 8A-D. Sternal submedian appendages of gonocoxites elongated triangular. Gonostylus bears four spinous bristles at apex and one subapical bristle medially, oblong process developed dorsally. Tergite IX oval, distal margin slightly concave. Cerci rounded, covered with irregularly arranged spines. Parameres relatively short, slightly sinuous, apically pointed.

Female unknown.

Remarks. B. subtriangularis is closely related to $B$. silvatica Dziedzicki, 1885 and B. triangularis Polevoi, 1995. It is distinguished by details of male genitalia structure: sternal submedian appendages of gonocoxites and dorsal process of the gonostylus are of intermediate length between $B$. silvatica (Fig. 8E, G) and $B$. triangularis (Fig. 8H, I); parameres in $B$. silvatica are much longer (Fig. 8F) and in B. triangularis apically clavate, with small lateral tooth (Fig. 8J).The material has been collected with Malaise
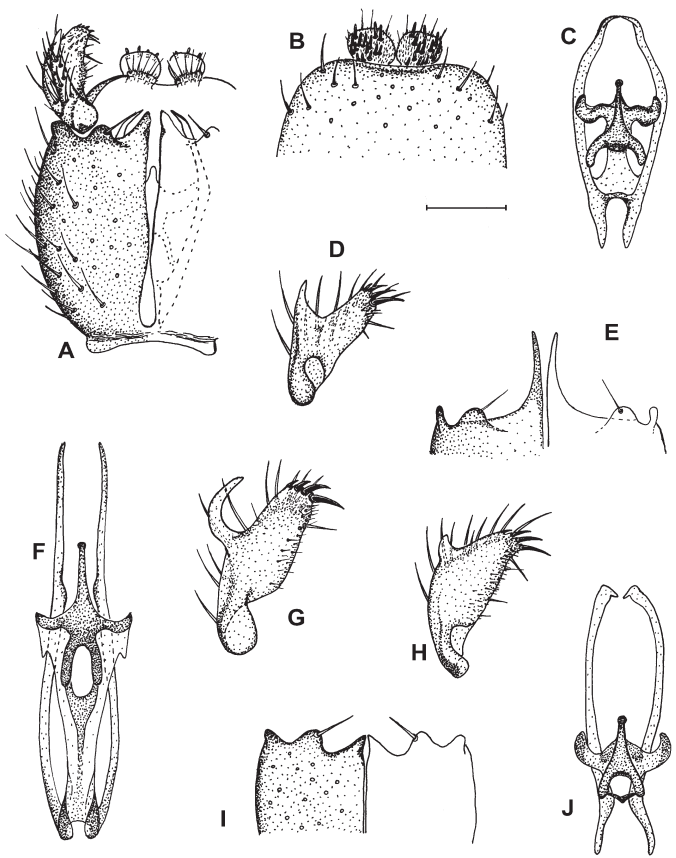

Fig. 8. Boletina spp. - A-D. B. subtriangularis sp. n.. E-G. B. silvatica Dziedzicki. - H-J. B. triangularis Polevoi (A: male genitalia, ventral view; B: tergite IX; C, F, J: aedeagus and parameres, ventral view; D, G, $\mathrm{H}$ : gonostylus; $\mathrm{E}$, I: sternal submedian appendages of gonocoxites). Scale bar $0.1 \mathrm{~mm}$.

traps and sweepnet in herbrich aspen stand and along small streams in forested ravines. Species' name indicates its resemblance to $B$. triangularis.

\section{Boletina atridentata sp. n. (Fig. 9A-E)}

Holotype: 1 ठ઼, Sweden, Lule Lappmark, Kvikkjokk, Prinskullestigen (600 m), 6.VIII.1997, Hedmark (ZISP). Paratypes: $1 \hat{\jmath}$, same data; $1 \hat{\jmath}$, Sweden, Lule Lappmark, Vuollerim, Vuollerimravinen (85 m), 17.VIII.2001, Hedmark (ZISP); 2 ふ઼ે, Russia, Karelia, Ks: 7358: 377, Paanajärvi Nat. Park, Alatalo (140 m), 1923.VIII.1999, Polevoi (ZISP).

Male. Head black. Clypeus and mouthparts black, palps dark brown. Antennae dark brown to almost black. Sixth flagellomere 1.2-1.5 times as long as wide. Mesonotum black, thinly grey dusted, with three faintly shining longitudinal stripes. Pleurae dark brown to almost black, thinly dusted. Laterotergite bare. Coxae, femora 

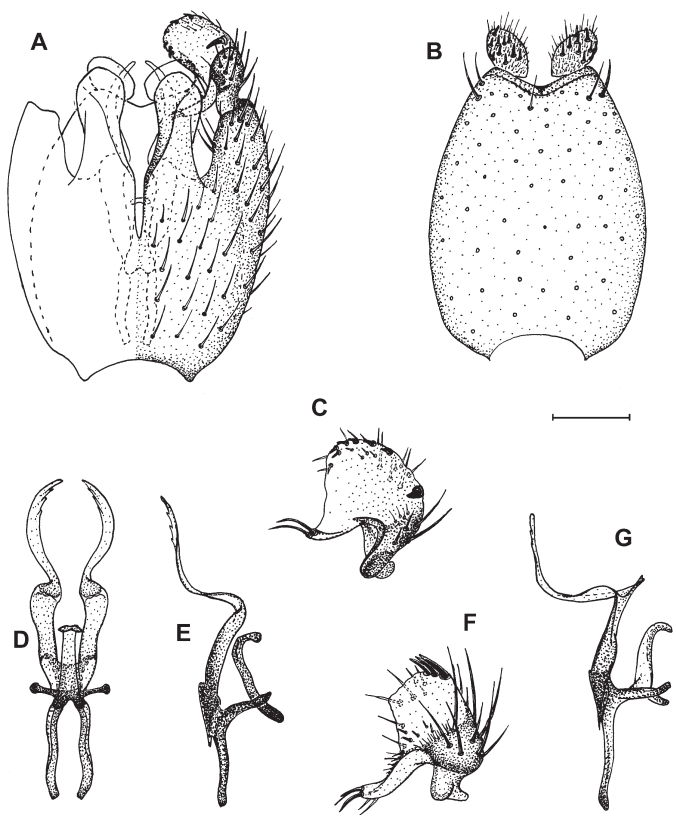

Fig. 9. Boletina spp. - A-E. B. atridentata sp. n. - FG. B. nigricans Dziedzicki (A: male genitalia, ventral view; B: tergite IX; C, F: gonostylus D: aedeagus and parameres, ventral view; E, G: same, lateral view;). Scale bars $0.12 \mathrm{~mm}(\mathrm{~A}, \mathrm{~B}, \mathrm{D}, \mathrm{E}, \mathrm{G})$ and $0.1 \mathrm{~mm}$ $(\mathrm{C}, \mathrm{F})$.

and tibiae yellow, trochanters darkened. Tarsal claws unmodified. Leg ratios: $\mathrm{t} 1$ :bt1 $=1.5-1.6$, $\mathrm{t} 2: \mathrm{bt} 2=1.5-1.7, \mathrm{t} 3: \mathrm{bt} 3=1.9-2.0$. Wing length 3.1-3.3 mm. Wings hyaline. Costa extending beyond tip of R5 to almost 1/2 of the distance between R5 and M1. Sc ending slightly beyond base of Rs. Sc2 present, somewhat distal to the middle of Sc. Stem of Median fork 1.4-1.5 times as long as rm. Halteres yellow. Abdomen and genitalia dark brown. Genitalia as in Fig. 9A-E. Sternal submedian appendages of gonocoxites rather long, apically rounded. Gonostylus with mediobasal process, bearing two bristles at apex. Distal part of gonostylus with one strong spine and 5-6 smaller spines along rounded apical margin. Tergite IX oval, distal margin distinctly concave. Cerci rounded, with short spines irregularly scattered over the surface. Parameres long, twice rectangularly bent near middle, distally serrate.

Female unknown.

Remarks. B. atridentata is closely related to $B$. nigricans Dziedzicki, 1885 and distinguished by details in the male genitalia structure. In the latter species gonostylus is subquadrate and bears distally three strong spines (two spines in some specimens) set close together (Fig. 9F), parameres with accessory median process best visible in lateral view (Fig. 9G). The material has been collected with sweepnet and Malaise traps in tallherb spruce and moist mixed stands. The species' name refers to the black teeth in the periphery of the gonostylus.

\section{Boletina cordata sp. n. (Fig. 10)}

Holotype: 1 ภ, Russia, Karelia, Kb: 6909:421, Tolvojärvi (170 m), 9-11.VI.1998, Tietäväinen (ZISP). Paratypes: 2 ๙ิ่, Finland, Kb: Tapionaho (170 m), 3-7.VI.1995, Polevoi (ZISP); 1 $\widehat{\jmath}$, Finland, Kb: 6987:725, Koitajoki (170 m), 31.VIII-4.IX.1996, Tietäväinen (ZISP); 1 ภ, Russia, Karelia, Ks: Paanajärvi Nat. Park, near lake Astervajärvi (200 m), 23.VI.1998, Polevoi (ZISP). 1 ภ̄, 3 oq, Russia, Karelia, Kb: 6909:421, Tolvojärvi (170 m), 2-11.VI.1999, Tietäväinen (ZISP).

Other material. Finland: 1 $\hat{\sigma}$, Kuusamo, R.Frey (1490, FMNH); Russia, Karelia: $1 \hat{\jmath}$, Kon: Kivach Nat. Res., 28.V-5.VI.1991, Polevoi (FRIP); 18 ふૈર, Kb: 6909:421, Tolvojärvi, 922.VI.1999, Tietäväinen (FRIP).

Male. Head black. Clypeus and labrum dark brown, remaining mouthparts and palps yellowish brown. Mouthparts elongated, almost as high as head. Scape yellowish brown, pedicel, first and base of the second flagellomere yellow (sometimes flagellomeres 1-3 entirely yellow), the rest of flagellum dark brown. Sixth flagellomere about twice as long as wide. Mesonotum black, thinly grey dusted, with three faint longitudinal stripes. Scutellum black. Pleurae dark brown, matt. Antepronotum and, sometimes, propleuron yellowish brown, anterior spiracles yellow. Yellowish areas usually developed on the anepimeron. Laterotergite haired. Coxae, femora and tibiae yellow, trochanters darkened. Posterior tarsal claws of fore and middle leg (in less extent of hind leg) significantly thickened and rounded. Anterior tarsal claws of all legs unmodified. Leg ratios: $\mathrm{t} 1: \mathrm{bt} 1=1.4-1.5, \mathrm{t} 2: \mathrm{bt} 2=1.5-1.6, \mathrm{t} 3: \mathrm{bt} 3=$ $1.7-1.8$. Wing length $5.1-5.5 \mathrm{~mm}$. Wings hyaline. Costa extending beyond tip of R5 to approx- 


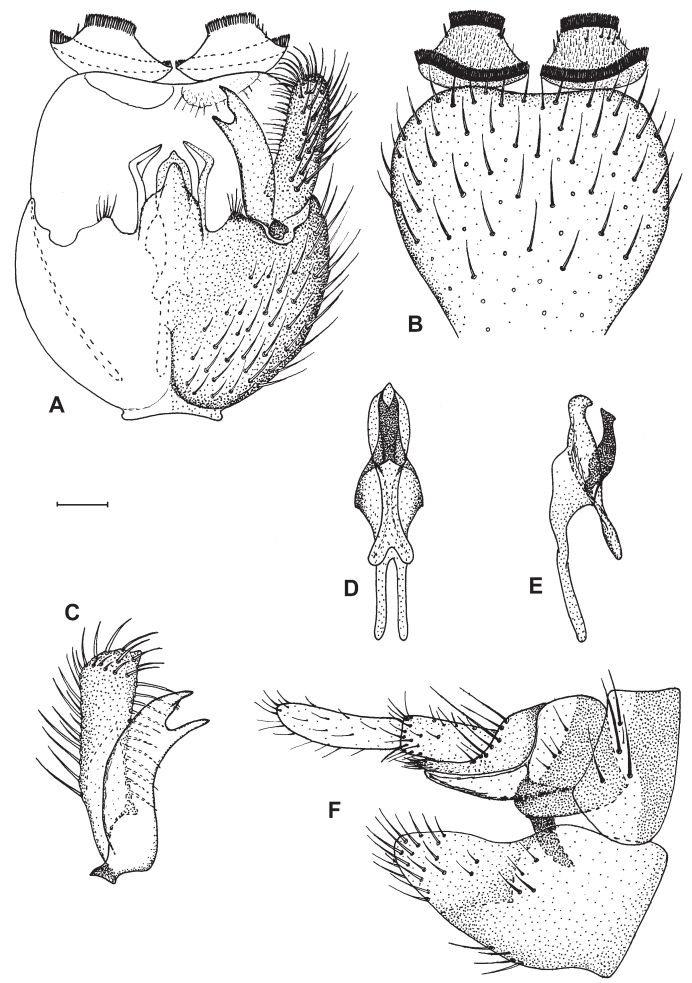

Fig. 10. Boletina cordata sp. n. - A. Male genitalia, ventral view. - B. Tergite IX. - C. Gonostylus. - D. Aedeagus, ventral view. - E. Same, lateral view. $-F$. Female terminalia, lateral view. Scale bars $0.13 \mathrm{~mm}$ $(\mathrm{A}, \mathrm{B}, \mathrm{F})$ and $0.1 \mathrm{~mm}(\mathrm{C}-\mathrm{E})$.

imately $1 / 3$ of the distance between R5 and M1. Sc usually setose in distal half, ending above, slightly beyond or before base of Rs. Sc2 present, distally to the middle of Sc. Stem of Median fork about as long as r-m. Halteres yellow. Abdomen dark brown with apicolateral yellow spots on tergites II-IV. Sometimes small yellowish spots also developed on tergites I and II, tergite IV sometimes entirely dark brown. Genitalia (Fig. 10AE) dark brown, yellowish ventrally. Sternite IX with median process and pair of submedian appendages. Ventral lobe of gonostylus bifurcate with pointed branches bearing no spines. Dorsal lobe with rudimentary apical process. Tergite IX cordate. Cerci wide with two dense combs of spines at apex and at base. Parameres short, fused apically.

Female. Similar to male, but more lightly coloured. Mesonotum yellow, dusted, with three dark-brown longitudinal stripes, middle stripe faint caudally. Dark brown spot developed above the base of the wing. Scutellum yellow. Pleurae mostly dark brown, but antepronotum and proepisternum yellowish brown, preepisternum 2 , laterotergite and mediotergite yellow in upper part, anepimeron with extensive yellow spot or completely yellowish brown. Anterior spiracles yellow. Abdomen black with pale distal bands on all tergites and sternites 1-6, sometimes obscure on distal segments. Female terminalia as in Fig. 10F. Both segments of cerci yellow.

Remarks. B. cordata is closely related to the group of species near $B$. lundbecki Lundström, 1912, but can be distinguished by the structure of male genitalia, especially the rudimentary apical process on dorsal lobe and absence of apical spines on ventral lobe of the gonostylus. The material has been collected with Malaise traps in coniferous stands of Myrtillus type. The species' name refers to the cordate shape of ninth tergite.

Acknowledgements. The authors are indebted to Geir Søli (Oslo) for valuable help in the initial stages of the study. Hans Helander's (Institution for Classical Languages, Uppsala University) advice in naming species and Peter Chandler's (Slough) information on British specimens are sincerely acknowledged. Pekka Vilkamaa (Helsinki) provided the possibility to study material deposited in the Finnish Museum of Natural History, Helsinki. Collecting and treatment of Finnish material in the Koitajoki and Kuhmo areas was financed by North Karelia Regional Environment Centre, Finnish Ministry of the Environment and partly by the Center of International Mobility. Collecting of Swedish material in the Kvikkjokk area was financed by Ájtte Museum, Jokkmokk. We sincerely thank Hannu Hokkanen, Markku Tietäväinen, Mikko Kuussaari and Harri Lappalainen for technical assistance and field work.

\section{References}

Blomberg, T., Hokkanen, T., Kaskor, V., Kokovkin, T., von Numers, M., Puurmann, E., Vuorio, V., Yakovlev, E. B. \& Öhman, M. 1999: The Biosphere Reserve concept in the Nordic countries and their cross-border regions. - TemaNord 522: 1-146.

Edwards, F. W. 1925: British Fungus-Gnats (Diptera, Mycetophilidae) with a revised generic classification of the family. — Trans. Ent. Soc. London 1924: 505670 .

Engelmark, O. 1981: Forest history of Muddus National 
Park, N Sweden. - Wahlenbergia 7: 33-38.

Hedmark, K. 1998: Fungus gnats - new species to Sweden and Finland (Diptera: Mycetophilidae s.lat.). Entomol. Tidskr. 119: 1-12. [In Swedish with English summary].

Hedmark, K. 2000: Fungus gnats in the taiga-new species from Sweden in a Fennoscandian perspective (Diptera: Sciaroidea excl. Sciaridae). - Entom. Tidskr. 121: 73-89. [In Swedish with English summary].

Heikinheimo, O. \& Raatikainen, M. 1971: The recording of locations of biological finds in Finland. - Ann. Entomol. Fennici 37: 1-27.

Heikkilä, R., Heikkilä, H., Polevoi, A. V. \& Yakovlev, E. B. (eds.) 2000: Biodiversity of old-growth forests and its conservation in northwestern Russia. — North Ostrobothnia Regional Environment Centre, Oulu. $206 \mathrm{pp}$.

Hokkanen, T. J. (ed.) 2001: Diversity studies in Koitajoki area (North Karelian Biosphere Reserve, Ilomantsi, Finland). - Metsähallitus, Vantaa. 217 pp.

Humala, A. E. 1998: Application of $33^{\circ} \mathrm{E}$ grid coordinate system for mapping of biological objects in conducting of biodiversity monitoring in Karelian-Kola region. In: Ecology of taiga forests. Abstracts of international conference September 14-18, 1998, Syktyvkar. Syktyvkar. Pp. 66-67.

Hutson, A. M., Ackland, D. M. \& Kidd, L. N. 1980: Mycetophilidae (Bolitophilinae, Ditomyiinae, Diadocidiinae, Keroplatinae, Sciophilinae and Manotinae), Diptera; Nematocera. - Handbooks for the Identification of British Insects 9(3): 1-111.

Karström, M. 1997: Indikatorarter för identifiering av naturskogar i Norrbotten. Del 2. Inventeringsrapport för Jokkmokks kommun. - Naturvårdsverket (SNV). Rapport 4692. 268 pp.

Komonen, A. 2001: Structure of insect communities inhabiting old-growth forest specialist bracket fungi. Ecol. Entomol. 26: 63-75.

Lindholm, T., Heikkilä, R. \& Heikkilä, M. (eds.) 1997: Ecosystems, fauna and flora of the Finnish-Russian
Nature Reserve Friendship. - Finnish Environment Institute, Helsinki. 364 pp.

Plassmann, E. 1990: Fünf neue Pilzmücken aus Schweden (Diptera, Nematocera, Mycetophilidae). - NachrB1. Bayer. Ent. 39: 61-64. Plassmann, E. 1999: Neue bayerische und schwedische Pilzmücken. - Mitt. Münch. Entomol. Gest. 89: 5-9.

Polevoi, A. V. 1995: New and poorly known species of the families Bolitophilidae, Diadocidiidae and Keroplatidae from Eastern Fennoscandia (Diptera, Nematocera). - Zoosystematica Rossica 4: 177-182. Polevoi, A. V. 2001: New and little known species of the fungus gnat subfamilies Mycomyinae and Sciophilinae (Diptera, Mycetophilidae) from Eastern Fennoscandia. — Entomol. Obozr. LXXX(2): 518526. [In Russian with English summary].

Salo, K. 1986: Kivatsu, nature reserve in the Karelian Autonomic Socialist Republik. — Luonnon Tutkija 90: 100-106. [In Finnish with English summary].

Søli, G. E. E. 1993: The first Palaearctic record of the mycetophilid genus Drepanocercus Vockeroth (Diptera: Mycetophilidae). — Ent. Scand. 24: 73-77.

Søli, G. E. E. 1994: Fungus gnats from Jostedalen, West Norway (Diptera; Diadocidiidae and Mycetophilidae). — Fauna Norv. Ser. B 41: 1-12.

Zaitzev, A. I. \& Polevoi, A. V. 1995: New species of fungus gnats (Diptera: Mycetophilidae) from Kivach Nature Reserve. - Entomol. Fennica 6: 185-195.

Zaitzev, A. I. \& Polevoi, A. V. 2001: Holarctic species of the Boletina erythropyga-group (Diptera, Mycetophilidae). — Studia dipterologica 8: 639-644.

Zaitzev, A. I. \& Økland, B. 1994: Four new species of fungus gnats from Norway (Diptera, Mycetophilidae). Studia Dipterologica 1: 181-186.

Økland, B. \& Zaitzev, A. I. 1997: Mycetophilids (Diptera, Sciaroidea) from southeastern Norway. - Fauna Norv. Ser. B 44: 27-37.

Økland, B. 1995: Description of Syntemna haagvari, a new species of Mycetophilidae (Diptera) from Norway. - Fauna Norv. Ser. B 42: 59-62. 